J. Clin. Chem. Clin. Biochem.

Vol. 28, 1990, pp. $225-231$

(C) 1990 Walter de Gruyter \& Co. Berlin · New York

\title{
The Diagnostic Value of Neuron-Specific Enolase and Carcino-Embryonic Antigen Analyses in Patients with Carcinoma of the Lung
}

\author{
By J. P. M. Wielders ${ }^{1}$, C. T. Bartels ${ }^{2}$, C. M. C. Bank ${ }^{1}$, J. C. E. Meek ${ }^{3}$, M. P. van Dieijen-Visser ${ }^{1}$
} and $P$. J. Brombacher ${ }^{1}$

Departments of Clinical Chemistry ${ }^{1}$ and Respiratory Diseases ${ }^{3}$, De Wever Hospital, Heerlen (NL) and Department of Clinical Chemistry ${ }^{2}$, St. Maartens Gasthuis, Venlo (NL)

(Received November 3, 1989/January 26, 1990)

Summary: Neuron-specific enolase and carcino-embryonic antigen were quantified simultaneously in sera of 135 patients attending the Department of Respiratory Diseases for diagnostic bronchoscopy. Fifteen small cell lung carcinomas, 24 non-small cell lung carcinomas and 96 benign pulmonary diseases were investigated. Lung biopsies or bronchial washings were obtained from about $75 \%$ of the patients, including all patients with neoplastic diseases. Serum neuron-specific enolase was measured by a recently introduced enzymeimmuno assay (WaKo NS-Enolase EIA-II testkit). The results obtained with this kit were similar to those based on RIA assays.

Receiver Operating Characteristic curves (ROC curves) were constructed for comparison of the discriminating ability of neuron-specific enolase and carcino-embryonic antigen in small cell lung carcinomas and non-small cell lung carcinomas. For small cell lung carcinomas the sensitivity and the specificity of neuron-specific enolase (cutoff value: $10 \mu \mathrm{g} / \mathrm{l}$ ) were $87 \%$ and $88 \%$, respectively, and for carcino-embryonic antigen values $60 \%$ and $77 \%$ were obtained. There was no correlation between neuron-specific enolase and carcino-embryonic antigen in small cell lung carcinoma patients. The diagnostic value of neuron-specific enolase and carcinoembryonic antigen in non-small cell lung carcinomas is illustrated by sensitivities of $13 \%$ and $58 \%$, respectively.

An extensive literature survey is included to allow comparison with other studies. The use of ROC curves is recommended for the determination of optimal cutoff values for the assays employed.

\section{Introduction}

Small cell carcinoma of the lung, which embryologically originates from neuronal tissue, constitutes 20 to $25 \%$ of all lung carcinomas. Small cell lung carcinoma is sensitive to radiotherapy and chemotherapy in about $80 \%$ of cases $(1,2)$. As an early start to the treatment is of utmost importance, a rapid and accurate diagnosis is essential. During recent years neuron-specific enolase has been given much attention both as a marker for small cell lung carcinomas and as a tool for follow-up and prognosis $(1-4)$. Current opinion is that next to bronchoscopy, neuron-specific enolase determination in serum might be a useful parameter for tumour detection and especially for monitoring the treatment of small cell lung carcinomas. However, especially for the limited form of the disease, the diagnostic sensitivity is low. Other lung tumours and neuroendocrine tumours can also secrete neuron-specific enolase (5).

Most studies have used radioimmunoassay, and control groups have often been composed of healthy persons or patients suffering from non-related diseases. We used a recently introduced enzyme immunoassay for neuron-specific enolase and investigated 
a group of 135 patients presented to the Department of Respiratory Diseases for diagnostic bronchoscopy. Carcino-embryonic antigen was also determined in the serum samples. Receiver Operating Characteristic curves (ROC curves; 6,7 ) were used to compare the value of neuron-specific enolase and carcino-embryonic antigen for the diagnosis of small cell lung carcinomas and non-small cell lung carcinomas, and to optimize the cutoff levels.

\section{Materials and Methods}

\section{Patients}

A total of 135 patients, attending the Department of Respiratory Diseases of the De Wever Hospital for diagnostic bronchoscopy, participated in this study. Biopsies or bronchial washings were obtained from about $75 \%$ of these patients, including all with apparent bronchoscopic abnormalities. Histological and cytological examinations performed by the Department of Pathology diagnosed small cell lung carcinomas (10 limited and 5 extended cases) or non-small cell lung carcinomas. Patients were classified in one of the categories, small cell lung carcinomas $(n=15)$, non-small cell lung carcinomas $(n=24)$ or benign pulmonary diseases $(n=96)$. Serum samples were obtained before the start of treatment. A number of small cell lung carcinoma patients was followed during chemotherapy, and serum samples were obtained two days before onset of the chemotherapy cycles.

\section{Neuron-specific enolase analysis}

Serum samples, free of haemolysis, were stored at $-20{ }^{\circ} \mathrm{C}$ until analysis. Neuron-specific enolase was quantified with the WaKO NS-Enolase (EIA)-II testkit from Amano Pharmaceutical Co (Distributor WaKo Pure Chemical Ind. Ltd., Osaka, Japan; Code No. 991-20001). In brief, neuron-specific enolase is bound to polyclonal rabbit anti-bovine neuron-specific enolase antibody immobilized to polystyrene beads. A sandwich is formed with $\beta$ - $D$-galactosidase-labelled monoclonal murine anti-neuron-specific enolase. After washing, the release of chlorophenol red from chlorophenol red- $\beta$ - $D$-galactopyranoside was measured photometrically. The reported neuron-specific enolase concentrations are the means of duplicate analyses.

\section{Carcino-embryonic antigen analysis}

Serum samples, free of haemolysis, were stored at $-20^{\circ} \mathrm{C}$ until analysis. Carcino-embryonic antigen was quantified with the Amerlite carcino-embryonic antigen assay from Amersham Int., Amersham, United Kingdom (Code LAN 0150 2150). This enhanced luminescence immunoassay uses a solid phase sheep anti-carcino-embryonic antigen polyclonal antibody and a mouse anti-carcino-embryonic antigen monoclonal antibody. Quantification by luminescence is performed by means of peroxidase-labelled sheep anti-mouse antibody and "Signal reagent" in the Amerlite Analyser. Carcino-embryonic antigen concentrations given are means of duplicate analyses.

\section{Statistical analysis}

Non-parametric tests were applied. The Wilcoxon two-sample test was used for testing tumour-marker level differences in patient subgroups. The Spearman rank correlation test was used for testing correlation between neuron-specific enolase and carcino-embryonic antigen concentrations.

\section{Results}

In our evaluation of the WaKo neuron-specific enolase kit we found intra- and inter-run coefficients of variation that agreed with those quoted by the manufacturers data, i. e. about 3 to $7 \%$ within run and 4 to $7 \%$ between runs. The analytical range is 1.7 to $135.0 \mu \mathrm{g} / \mathrm{l}$. Higher concentrations were measured after dilution of the sample with $9 \mathrm{~g} / \mathrm{l}$ saline solution. The results of the neuron-specific enolase analyses are presented in figure 1 . The mean neuron-specific enolase concentration for 5 patients with extensive small cell lung carcinomas was $88.2 \mu \mathrm{g} / \mathrm{l}$. For limited small cell lung carcinomas $(\mathrm{n}=10)$ and for non-small cell lung carcinomas $(n=24)$, the mean neuron-specific enolase concentrations were $18.0 \mu \mathrm{g} / 1$ and $6.6 \mu \mathrm{g} / \mathrm{l}$, respectively.

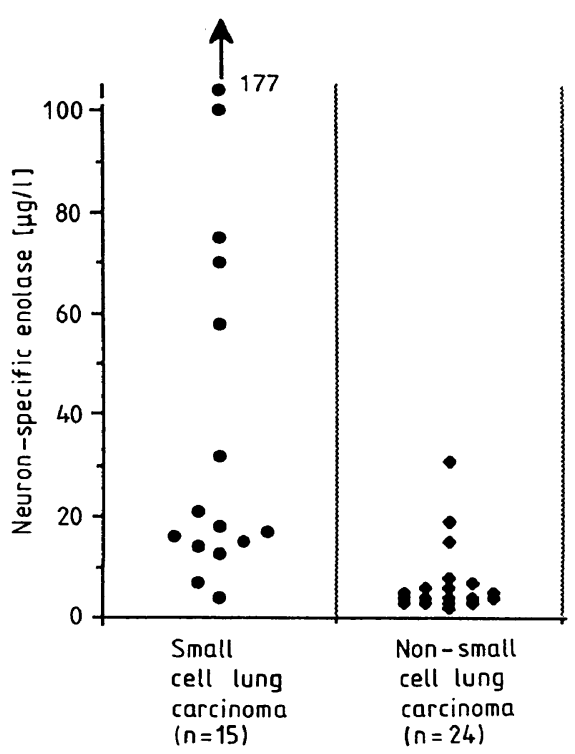

Fig. 1. Concentration of neuron-specific enolase in the sera of patients with small cell lung carcinoma and non-small cell lung carcinoma.

The neuron-specific enolase levels in the pre-treatment samples of the extended small cell lung carcinoma group were significantly higher than in the limited small cell lung carcinoma group according to the Wilcoxon test $(\mathrm{p}<0.01)$. We found no significant difference between the levels of carcino-embryonic antigen in the extended small cell lung carcinoma and the limited small cell lung carcinoma group (Wilcoxon test, $\mathrm{p}<0.05$ ).

Neither a positive nor a negative correlation could be detected between the neuron-specific enolase and the carcino-embryonic antigen levels in the sera of the whole small cell lung carcinoma group $(n=15)$ (Spearman rank test, $\mathrm{p}<0.01$ ). In order to compare the discriminating abilities of neuron-specific enolase and carcino-embryonic antigen, both for small cell 
lung carcinomas and non-small cell lung carcinomas, ROC curves were constructed (figs. 2 and 3).

As shown by figure 2, neuron-specific enolase clearly has advantages over carcino-embryonic antigen for the detection of small cell lung carcinomas. Based on the ROC curve an optimal cutoff value of $10 \mu \mathrm{g} / \mathrm{l}$ was selected (asterisk in fig. 2). At this cutoff value the sensitivity and specificity were $87 \%$ and $88 \%$, respectively. The maximal value for the sum of sensitivity and specificity was about $180 \%$ for neuron-specific enolase in small cell lung carcinomas. For carcinoembryonic antigen the maximal sum was about $130 \%$ in small cell lung carcinomas. The test efficiency for neuron-specific enolase in small cell lung carcinoma detection, defined as the number of true positives plus

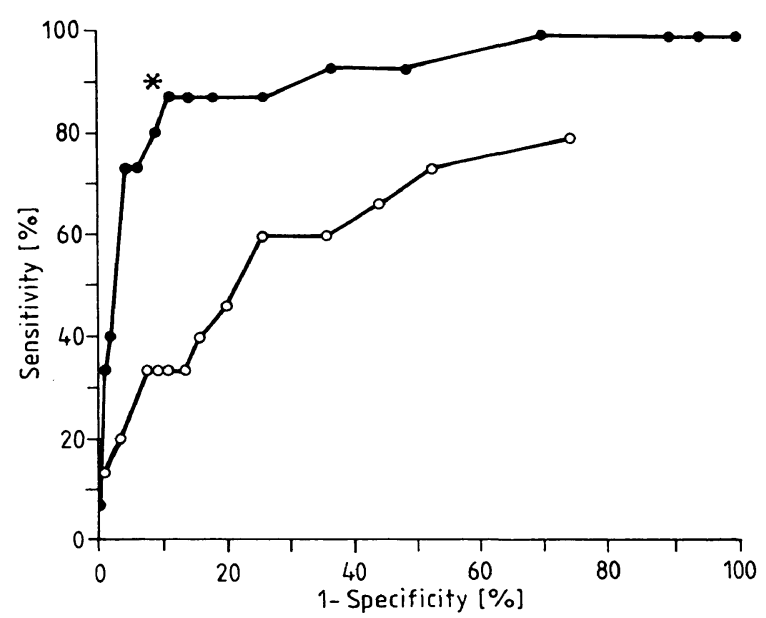

Fig. 2. Receiver operating characteristic (ROC) curves of neuron-specific enolase $(\bullet-\bullet)$ and carcino-embryonic antigen $(\mathrm{O}-\mathrm{O})$ for the diagnosis of small cell lung carcinoma.

$*=$ Cutoff value

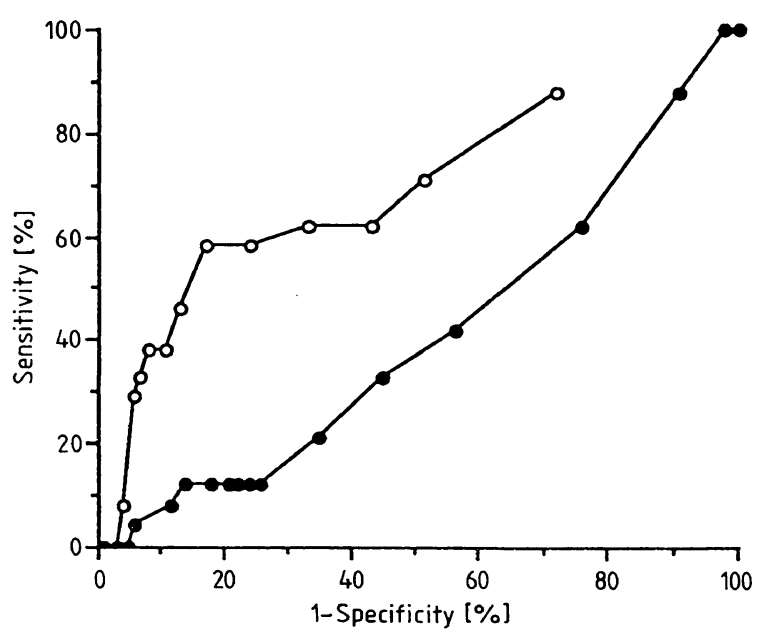

Fig. 3. Receiver operating characteristic (ROC) curves of neuron-specific enolase $(\bullet-\bullet)$ and carcino-embryonic antigen $(\mathrm{O}-\mathrm{O})$ for the diagnosis of non-small cell lung carcinoma. the number of true negatives divided by the total number of patients, was $89 \%$ at the cutoff value 10.0 $\mu \mathrm{g} / \mathrm{l}$.

As shown in figure 3 , the measurement of serum neuron-specific enolase has no value for the detection of non-small cell lung carcinomas, while carcino-embryonic antigen has at least some discriminating ability. The maximal sum of sensitivity and specificity was about $110 \%$ for neuron-specific enolase and $140 \%$ for carcino-embryonic antigen in non-small cell lung carcinomas.

\section{Follow up of patients}

Longitudinal analyses were performed for a number of small cell lung carcinoma patients. The results for a case of limited small cell lung carcinoma and extended small cell lung carcinomas are presented. Patient F-L (fig. 4) was a 70 year old woman with the diagnosis of limited small cell lung carcinoma, who showed a partial remission after 5 chemotherapy cycles. However, after 8 months a relapse was noticed with cerebral and liver metastases and greatly increased neuron-specific enolase levels.

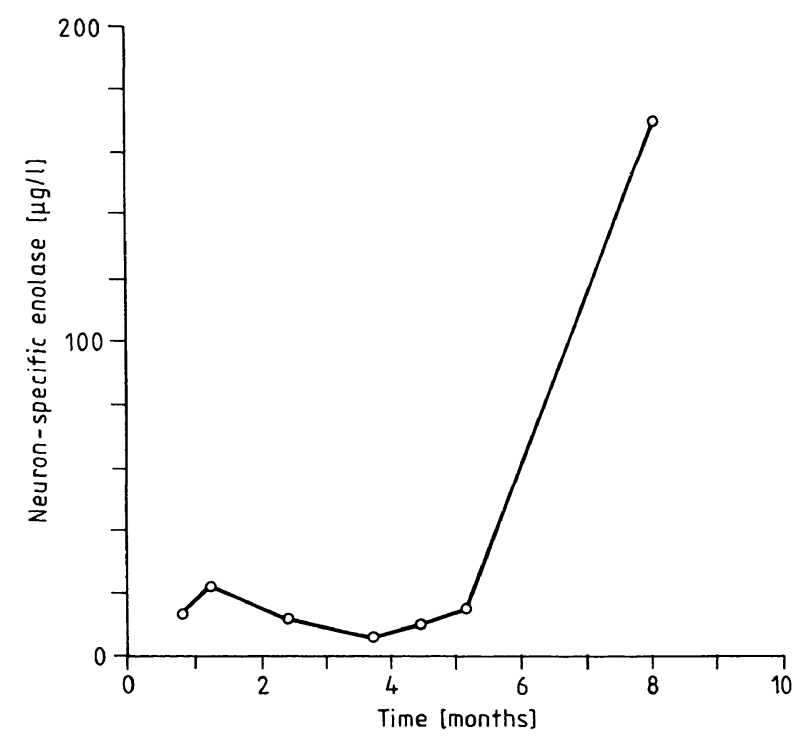

Fig. 4. Course of the serum neuron-specific enolase in patient F-L (limited small cell lung carcinoma) after the initial diagnosis.

Patient $M$ (figure 5) was a 70 year old man with the diagnosis of extended small cell lung carcinoma with bone and liver metastases. Partial remission was seen after 5 chemotherapy cycles. No tumour could be found at bronchoscopy or X-thorax at 7 months after the initial diagnosis. However, 3 months later a relapse occurred with a sharp increase in neuron-specific enolase. 


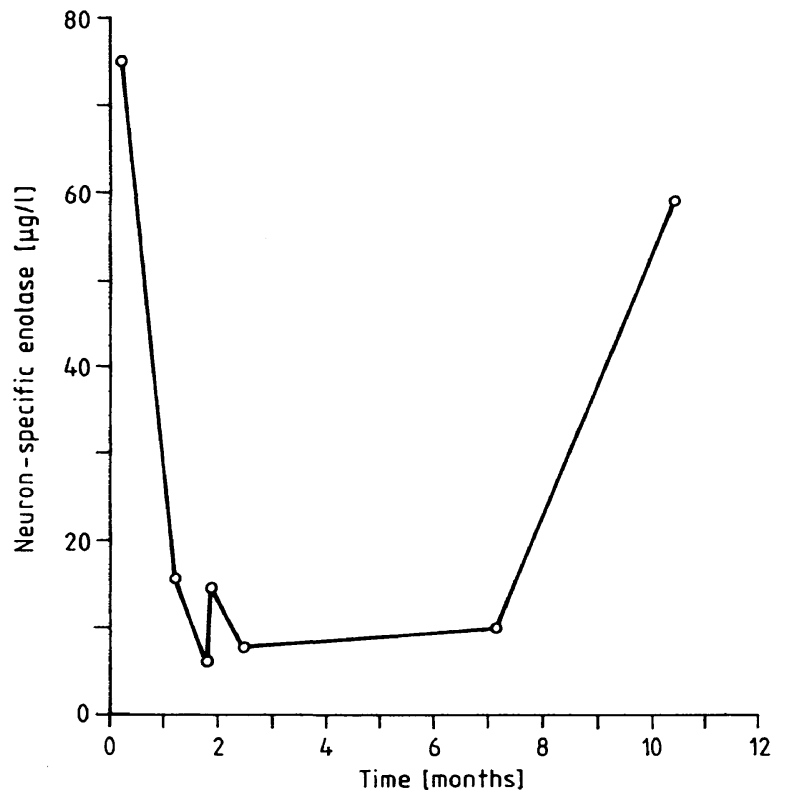

Fig. 5. Course of the serum neuron-specific enolase in patient $M$ (extended small cell lung carcinoma) after the initial diagnosis.

\section{Discussion}

After the first report by Carney et al. (1) on the diagnostic benefits of neuron-specific enolase in small cell lung carcinomas, a number of studies have been performed on this subject. In most studies RIA methods have been employed for the neuron-specific enolase analysis. In table 1 a literature survey $(9-22)$ is presented with emphasis on serum neuron-specific enolase in small cell lung carcinomas. The presence of high neuron-specific enolase levels in neuroblastomas and other malignancies $(5,8)$ is beyond the scope of our study.

It can be seen from table 1 that neuron-specific enolase is useful for detecting and monitoring small cell lung carcinomas. A comparison of the various studies is, however, difficult, due to differences in methods and selection of cutoff values (range $6-20 \mu \mathrm{g} / \mathrm{l}$ ). Many authors used a cutoff value derived from the "normal values" of a reference population: mean plus two or three standard deviations. Other authors used quite arbitrary levels. For example a $25 \mu \mathrm{g} / 1$ cutoff value was chosen as a "more discriminative limit" $(4$, $9,10)$.

Improvement of specificity inherently leads to a decreased sensitivity of the tumour marker, as shown by ROC curves $(6,7)$. It must be kept in mind that especially the specificity data are dependent on the reference (control) group used, as demonstrated in table 1. In our opinion it is preferable to consider a random group of patients elected for bronchoscopy, including possible lung-carcinomas as a reference for evaluating neuron-specific enolase and small cell lung carcinomas, instead of a group of healthy controls or patients with unrelated diseases. In figure 2 all patients without the diagnosis small cell lung carcinoma or non-small cell lung carcinoma, served as the reference group.

The optimal cutoff value for neuron-specific enolase, defined as the highest level corresponding to nondisease, was derived from figure $2(10 \mu \mathrm{g} / \mathrm{l})$. Although our cutoff value was obtained by a completely different approach, it is equal to the one used by Gerbitz (17) and Tamura (22) for their RIA assays. In general the cutoff values used in RIA methods are higher than in EIA methods (tab. 1). Methodological differences include the use of polyclonals versus monoclonals, or possibly measurement of the $\alpha \gamma$-isoenzyme as well as the $\gamma \gamma$-isoenzyme (e.g. 1.c. (26)). The WaKo kit is based on a monoclonal antibody specific for the $\gamma \gamma$-isoenzyme. The frequently used Pharmacia RIA assay is based on polyclonal antibodies binding the $\alpha \gamma$ as well as the $\gamma \gamma$-isoenzyme.

Table 2 presents a survey of literature on serum carcino-embryonic antigen levels in small cell lung carcinomas and non-small cell lung carcinomas $(11,18$, $22-25)$. As in the studies using neuron-specific enolase, a comparison of data is difficult, owing to differences in methods and selection of cutoff values. From the ROC curve presented in figure 2 we derived a $2.5 \mu \mathrm{g} / 1$ cutoff value, which is lower than in other studies (tab. 2).

In our study the generally used tumour marker, carcino-embryonic antigen, appeared to be of less value for small cell lung carcinomas than the more specific marker, neuron-specific enolase (see fig. 2). Waalkes (25) found that pretreatment carcino-embryonic antigen levels generally showed a correlation with the stage of the disease and "not uncommonly" rose at the relapse. However, later studies favoured neuronspecific enolase rather than carcino-embryonic antigen for the detection and follow-up of small cell lung carcinomas. The same conclusion can be drawn from a comparison of the data in the tables 1 and 2 .

It can be concluded from an extensive literature survey that the results obtained with the WaKo kit for neuron-specific enolase are very similar to those published for RIA or other EIA methods. Neuron-specific enolase analysis is clearly superior to carcino-embryonic antigen in the diagnosis of small cell lung carcinoma. Extended small cell lung carcinoma corresponds to significantly higher neuron-specific enolase levels than limited small cell lung carcinoma. Neuron-specific enolase measurements are useful in the follow-up of 
Tab. 1. Survey of studies on serum neuron-specific enolase (NSE) in pretreatment small cell lung carcinomas (SCLC) and nonsmall cell lung carcinomas (N-SCLC).

\begin{tabular}{|c|c|c|c|c|c|c|c|c|}
\hline \multirow{2}{*}{$\begin{array}{l}\text { Study, } \\
\text { 1st author }\end{array}$} & \multirow[t]{2}{*}{ Diagnosis } & \multirow{2}{*}{$\begin{array}{l}\text { Cutoff } \\
(\mu \mathrm{g} / \mathrm{l})\end{array}$} & \multicolumn{2}{|c|}{ Sensitivity } & \multirow[t]{2}{*}{ Controls } & \multicolumn{2}{|c|}{ Specificity } & \multirow[t]{2}{*}{ Method } \\
\hline & & & $(\%)$ & cases & & $(\%)$ & cases & \\
\hline $\begin{array}{l}\text { Adewole } \\
\text { (1987) }\end{array}$ & $\begin{array}{l}\text { SCLC } \\
\text { lim. SCLC } \\
\text { ext. SCLC }\end{array}$ & $\begin{array}{l}12.5 \\
12.5 \\
12.5\end{array}$ & $\begin{array}{r}65 \\
0 \\
76\end{array}$ & $\begin{array}{c}13 / 20 \\
0 / 3 \\
13 / 17\end{array}$ & $\begin{array}{l}\text { Lymphomas and } \\
\text { non-lung carcinoma }\end{array}$ & 100 & $41 / 41$ & $\begin{array}{l}\text { RIA (Pharmacia), } \\
\text { cutoff suggested } \\
\text { by manufacturer }\end{array}$ \\
\hline $\begin{array}{l}\text { Akoun } \\
\text { (1985) }\end{array}$ & $\begin{array}{l}\text { SCLC } \\
\text { lim. SCLC } \\
\text { ext. SCLC } \\
\text { N-SCLC }\end{array}$ & $\begin{array}{l}16 \\
16 \\
16 \\
16\end{array}$ & $\begin{array}{l}65 \\
38 \\
82 \\
14\end{array}$ & $\begin{array}{r}28 / 43 \\
6 / 16 \\
22 / 27 \\
2 / 14\end{array}$ & Healthy adults & 97 & $34 / 35$ & $\begin{array}{l}\text { EIA (Own method), } \\
\text { cutoff = mean plus } \\
2 \text { s.d. of controls }\end{array}$ \\
\hline $\begin{array}{l}\text { Anastasiades } \\
(1986)\end{array}$ & $\begin{array}{l}\text { SCLC } \\
\text { N-SCLC }\end{array}$ & $\begin{array}{l}8.8 \\
8.8\end{array}$ & $\begin{array}{r}100 \\
0\end{array}$ & $\begin{array}{l}7 / 7 \\
0 / 9\end{array}$ & Healthy volunteers & 100 & $20 / 20$ & $\begin{array}{l}\text { ELISA } \\
\text { (Own method), } \\
\text { cutoff = upper limit } \\
\text { normal range }\end{array}$ \\
\hline $\begin{array}{l}\text { Ariyoshi } \\
\text { (1983) }\end{array}$ & $\begin{array}{l}\text { SCLC } \\
\text { N-SCLC }\end{array}$ & $\begin{array}{l}7.5 \\
7.5\end{array}$ & $\begin{array}{l}65 \\
11\end{array}$ & $\begin{array}{r}13 / 20 \\
6 / 54\end{array}$ & Normal subjects & 100 & $80 / 80$ & $\begin{array}{l}\text { EIA (Own method), } \\
\text { cutoff tentatively set }\end{array}$ \\
\hline $\begin{array}{l}\text { Bork } \\
(1988)\end{array}$ & $\begin{array}{l}\text { SCLC } \\
\text { lim. SCLC } \\
\text { ext. SCLC }\end{array}$ & $\begin{array}{l}15 \\
15 \\
15\end{array}$ & $\begin{array}{l}40 \\
14 \\
72\end{array}$ & $\begin{array}{r}10 / 24 \\
2 / 14 \\
8 / 11\end{array}$ & & & & $\begin{array}{l}\text { RIA (acc. to Paus), } \\
\text { cutoff = normal up- } \\
\text { per reference limit }\end{array}$ \\
\hline $\begin{array}{l}\text { Carney } \\
(1982)\end{array}$ & $\begin{array}{l}\text { SCLC } \\
\text { lim. SCLC } \\
\text { ext. SCLC }\end{array}$ & $\begin{array}{l}12 \\
12 \\
12\end{array}$ & $\begin{array}{l}69 \\
39 \\
88\end{array}$ & $\begin{array}{l}65 / 94 \\
15 / 38 \\
49 / 56\end{array}$ & Healthy adults & 100 & $30 / 30$ & $\begin{array}{l}\text { RIA (Own method), } \\
\text { cutoff = mean plus } \\
3 \text { s.d. of controls }\end{array}$ \\
\hline $\begin{array}{l}\text { Cooper } \\
(1985)\end{array}$ & $\begin{array}{l}\text { SCLC } \\
\lim . \text { SCLC } \\
\text { ext. SCLC } \\
\text { N-SCLC }\end{array}$ & $\begin{array}{l}12.5 \\
12.5 \\
12.5 \\
12.5\end{array}$ & $\begin{array}{l}77 \\
66 \\
87 \\
17\end{array}$ & $\begin{array}{l}59 / 77 \\
25 / 38 \\
34 / 39 \\
16 / 94\end{array}$ & $\begin{array}{l}\text { Blood donors } \\
\text { Metastatic lung } \\
\text { tumours, benign } \\
\text { lung lesions, bron- } \\
\text { chopneumonias }\end{array}$ & $\begin{array}{l}94 \\
78\end{array}$ & $\begin{array}{l}31 / 33 \\
32 / 41\end{array}$ & $\begin{array}{l}\text { RIA (Pharmacia), } \\
\text { cutoff suggested } \\
\text { by manufacturer }\end{array}$ \\
\hline $\begin{array}{l}\text { Esscher } \\
(1985)\end{array}$ & $\begin{array}{l}\text { SCLC } \\
\text { lim. SCLC } \\
\text { ext. SCLC } \\
\text { N-SCLC }\end{array}$ & $\begin{array}{l}12 \\
12 \\
12 \\
12\end{array}$ & $\begin{array}{l}85 \\
71 \\
98 \\
25\end{array}$ & $\begin{array}{l}88 / 103 \\
34 / 48 \\
54 / 55 \\
13 / 51\end{array}$ & $\begin{array}{l}\text { Blood donors plus } \\
\text { healthy employees } \\
\text { Benign diseases of } \\
\text { lung/mediastinum }\end{array}$ & 99 & $151 / 152)$ & $\begin{array}{l}\text { RIA (Own method), } \\
\text { cutoff = mean plus } \\
3 \text { s.d. of controls }\end{array}$ \\
\hline $\begin{array}{l}\text { Fishbach } \\
(1986)\end{array}$ & $\begin{array}{l}\text { SCLC } \\
\text { N-SCLC }\end{array}$ & $\begin{array}{l}11 \\
11\end{array}$ & $\begin{array}{l}86 \\
20\end{array}$ & $\begin{array}{l}6 / 7 \\
3 / 15\end{array}$ & $\begin{array}{l}\text { Blood donors } \\
\text { Benign lung lesions }\end{array}$ & $\begin{array}{l}97 \\
95\end{array}$ & $\begin{array}{c}115 / 119 \\
38 / 40\end{array}$ & $\begin{array}{l}\text { RIA (Pharmacia), } \\
\text { cutoff = mean plus } \\
2 \text { s.d. of controls }\end{array}$ \\
\hline $\begin{array}{l}\text { Fujita } \\
\text { (1987) }\end{array}$ & $\begin{array}{l}\text { SCLC } \\
\text { N-SCLC }\end{array}$ & $\begin{array}{l}6 \\
6\end{array}$ & $\begin{array}{l}78 \\
25\end{array}$ & $\begin{array}{l}14 / 18 \\
15 / 60\end{array}$ & $\begin{array}{l}\text { Healthy subjects, } \\
\text { mainly blood donors }\end{array}$ & 100 & $100 / 100$ & $\begin{array}{l}\text { EIA (Own method), } \\
\text { cutoff = mean plus } \\
3 \text { s.d. of controls }\end{array}$ \\
\hline $\begin{array}{l}\text { Gerbitz } \\
(1986)\end{array}$ & $\begin{array}{l}\text { SCLC } \\
\text { lim. SCLC } \\
\text { ext. SCLC } \\
\text { N-SCLC }\end{array}$ & $\begin{array}{l}10 \\
10 \\
10 \\
10\end{array}$ & $\begin{array}{r}100 \\
100 \\
100 \\
17\end{array}$ & $\begin{array}{c}27 / 27 \\
8 / 8 \\
19 / 19 \\
5 / 29\end{array}$ & Healthy subjects & 100 & $20 / 20$ & $\begin{array}{l}\text { RIA (Pharmacia) } \\
\text { cutoff was set at } \\
10 \mu \mathrm{g} / 1 \\
\text { NSE in plasma! }\end{array}$ \\
\hline $\begin{array}{l}\text { Johnson } \\
\text { (1984) }\end{array}$ & SCLC & 20 & 73 & $68 / 93$ & Healthy adults & 100 & $20 / 20$ & $\begin{array}{l}\text { RIA (Pharmacia) } \\
\text { cutoff = mean plus } \\
3 \text { s.d. of controls }\end{array}$ \\
\hline $\begin{array}{l}\text { Kato } \\
(1985)\end{array}$ & SCLC & 12 & 89 & $8 / 9$ & Healthy subjects & 100 & $33 / 33$ & $\begin{array}{l}\text { EIA, similar to } \\
\text { WaKo-kit }\end{array}$ \\
\hline $\begin{array}{l}\text { Tamura } \\
\text { (1987) }\end{array}$ & $\begin{array}{l}\text { SCLC } \\
\text { lim. SCLC } \\
\text { ext. SCLC }\end{array}$ & $\begin{array}{l}10 \\
10 \\
10\end{array}$ & $\begin{array}{l}58 \\
38 \\
65\end{array}$ & $\begin{array}{c}14 / 24 \\
3 / 8 \\
11 / 16\end{array}$ & & 100 & $18 / 18$ & RIA (Eiken, Tokyo) \\
\hline $\begin{array}{l}\text { Togawa } \\
\text { (1987) }\end{array}$ & $\begin{array}{l}\text { SCLC } \\
\text { N-SCLC }\end{array}$ & $\begin{array}{l}11 \\
11\end{array}$ & $\begin{array}{l}83 \\
28\end{array}$ & $\begin{array}{l}10 / 12 \\
11 / 40\end{array}$ & Healthy adults & 100 & $25 / 25$ & RIA (Eiken, Tokyo) \\
\hline Our study & $\begin{array}{l}\text { SCLC } \\
\text { N-SCLC }\end{array}$ & $\begin{array}{l}10 \\
10\end{array}$ & $\begin{array}{l}87 \\
13\end{array}$ & $\begin{array}{r}13 / 15 \\
3 / 24\end{array}$ & $\begin{array}{l}\text { N-SCLC, pneumo- } \\
\text { nia, benign lung } \\
\text { diseases }\end{array}$ & 88 & $107 / 135$ & $\begin{array}{l}\text { EIA (WaKo kit) } \\
\text { cutoff derived } \\
\text { from ROC curve }\end{array}$ \\
\hline
\end{tabular}


Tab. 2. Survey of studies on serum carcino-embryonic antigen (CEA) in pretreatment small cell lung carcinomas (SCLC) and non-small cell lung carcinomas (N-SCLC).

\begin{tabular}{|c|c|c|c|c|c|}
\hline \multirow{2}{*}{$\begin{array}{l}\text { Study, } \\
\text { 1st author }\end{array}$} & \multirow[t]{2}{*}{ Diagnosis } & \multirow{2}{*}{$\begin{array}{l}\text { Cutoff } \\
(\mu \mathrm{g} / \mathrm{l})\end{array}$} & \multicolumn{2}{|c|}{ Sensitivity } & \multirow[t]{2}{*}{ Method } \\
\hline & & & $(\%)$ & cases & \\
\hline $\begin{array}{l}\text { Adewole } \\
\text { (1987) }\end{array}$ & SCLC & 10 & 53 & $8 / 15$ & RIA, Kemtek \\
\hline $\begin{array}{l}\text { Ganz } \\
(1987)\end{array}$ & SCLC & 5 & 48 & $23 / 48$ & RIA, Roche \\
\hline $\begin{array}{l}\text { Jacques } \\
\text { (1988) }\end{array}$ & $\begin{array}{l}\text { SCLC } \\
\text { lim. SCLC } \\
\text { ext. SCLC }\end{array}$ & $\begin{array}{l}5 \\
5 \\
5\end{array}$ & $\begin{array}{l}44 \\
39 \\
44\end{array}$ & $\begin{array}{l}84 / 193 \\
27 / 62 \\
57 / 129\end{array}$ & EIA, Abott \\
\hline $\begin{array}{l}\text { Krauss } \\
(1981)\end{array}$ & $\begin{array}{l}\text { SCLC } \\
\text { lim. SCLC } \\
\text { ext. SCLC } \\
\text { N-SCLC }\end{array}$ & $\begin{array}{l}6.5 \\
6.5 \\
6.5 \\
6.5\end{array}$ & $\begin{array}{l}40 \\
24 \\
62 \\
50\end{array}$ & $\begin{array}{r}24 / 60 \\
8 / 34 \\
16 / 26 \\
24 / 48\end{array}$ & \\
\hline $\begin{array}{l}\text { Tamura } \\
\text { (1987) }\end{array}$ & $\begin{array}{l}\text { SCLC } \\
\text { lim. SCLC } \\
\text { ext. SCLC }\end{array}$ & $\begin{array}{l}5 \\
5 \\
5\end{array}$ & $\begin{array}{l}29 \\
13 \\
38\end{array}$ & $\begin{array}{l}7 / 24 \\
1 / 8 \\
6 / 16\end{array}$ & RIA, Dinabott \\
\hline $\begin{array}{l}\text { Waalkes } \\
(1980)\end{array}$ & $\begin{array}{l}\text { SCLC } \\
\text { lim. SCLC } \\
\text { ext. SCLC }\end{array}$ & $\begin{array}{l}5 \\
5 \\
5\end{array}$ & $\begin{array}{l}48 \\
21 \\
61\end{array}$ & $\begin{array}{r}20 / 42 \\
3 / 14 \\
17 / 28\end{array}$ & $\begin{array}{l}\text { RIA, } \\
\text { acc. to Hansen }\end{array}$ \\
\hline Our study & $\begin{array}{l}\text { SCLC } \\
\text { N-SCLC }\end{array}$ & $\begin{array}{l}2.5 \\
2.5\end{array}$ & $\begin{array}{l}60 \\
58\end{array}$ & $\begin{array}{r}9 / 15 \\
14 / 24\end{array}$ & $\begin{array}{l}\text { Enhanced Luminescence } \\
\text { Immunoassay, Amersham }\end{array}$ \\
\hline
\end{tabular}

the disease and the monitoring of the results of treatment. The comparison of different studies is difficult, owing to differences in methods, cutoff values and reference groups.

\section{References}

1. Carney, D. N., Ihde, D. C., Cohen, M. H., Marangos, P. J., Bunn, P. A. Jr., Minna, J. D. \& Gazdar, A. F. (1982) Serum neuron-specific enolase: A marker for disease extend and response to therapy of small-cell lung cancer. Lancet $I, 583-585$.

2. Splinter, T. A. W., Cooper, E. H., Kho, G. S., Oosterom, R. \& Peake, M. D. (1987) Doubling time of neuron specific enolase and survival in small cell lung cancer patients. Results of a preliminary analysis. European J. Clin. Oncology 23, 171-176.

3. Kaiser, E., Kuzmits, R., Pregant, P., Burghuber, O. \& Worofka, W. (1989) Clinical biochemistry of neuron specific enolase. Clin. Chim. Acta 183, 13-21.

4. Cooper, E. H., Splinter, T. A. W., Brown, D. A., Muers, M. F., Peake, M. D. \& Pearson, S. L. (1985) Evaluation of a radioimmunoassay for neuron specific enolase in small cell lung cancer. Br. J. Cancer 52, 333-338.

5. Tapia, F. J., Barbosa, A. J. A., Marangos, P. J., Polak, J. M., Bloom, S. R., Dermody, C. \& Pearse, A. G. E. (1981) Neuron specific enolase is produced by neuro-endocrine tumours. Lancet $I, 808-811$.

6. Gerhard, W. \& Keller, H. (1986) Evaluation of test data from clinical studies. Scand. J. Clin. Lab. Invest. 46 suppl. 181.

7. Beck, J. R. \& Shultz, E. K. (1986) The use of ROC curves in test performance evaluation. Arch. Pathol. Lab. Med. $110,13-20$.

\section{Acknowledgements}

The performance of the histological and cytological analyses by the Department of Pathology (head: Dr. J. Koudstaal) and the tumour marker analyses by Brigitte Kohlen are gratefully acknowledged.

8. Zeltzer, P. M., Marangos, P. J., Evans, A. E. \& Schneider, S. L. (1986) Serum neuron-specific enolase in children with neuroblastoma. Cancer 57, 1230-1234.

9. Esscher, T., Steinholtz, L., Bergh, J. Nöu, E., Nilsson, K. \& Påhlman, S. (1985) Neuron specific enolase: a useful diagnostic serum marker for small cell carcinoma of the lung. Thorax 40, 85-90.

10. Fishbach, W., Jany, B. \& Nelkenstock, R. (1986) Bedeutung der neuronspezifische Enolase in der Diagnostik von Bronchialkarzinomen und neuroendokrinen Tumoren. Dtsch. Med. Wochenschr. 111, 1721-1725.

11. Adewole, I. F. \& Newlands, E. S. (1987) Neuron-specific enolase as a tumor marker and comparative evaluation with carcinoembryonic antigen in small-cell lung cancer. Med. Oncol. Tumor Pharmacother. 4, 11-15.

12. Akoun, G. M., Scarna, H. M., Milleron, B. J., Benichou, M. P. \& Herman, D. P. (1985) Serum neuron-specific enolase. A marker for disease extend and response to therapy for small-cell lung cancer. Chest 87, 39-43.

13. Anastasiades, K. D., Mullins, R. E. \& Conn, R. B. (1987) Neuron-specific enolase. Assessment by ELISA in patients with small cell carcinoma of the lung. Am. J. Clin. Pathol $87,245-249$.

14. Ariyoshi, Y., Kato, K., Ishiguro, Y., Ota, K., Sato, T. \& Suchi, T. (1983) Evaluation of serum NSE as marker for carcinoma of the lung. Jpn. J. Cancer Res. (Gann) 74, $225-231$. 
15. Bork, E., Hansen, M., Urdal, P., Paus, E., Holst, J. J., Schiffer, S., Fenger, M. \& Engbaek, F. (1988) Early detection of response in small cell bronchogenic carcinoma by changes in serum concentrations of creatine kinase, neuron specific enolase, calcitonin, $\mathrm{ACTH}$, serotonine and gastrin releasing peptide. Eur. J. Cancer Clin. Oncol. 24, $1033-$ 1038.

16. Fujita, K., Haimoto, H., Imaizumi, M., Abe, T. \& Kato, K. (1987) Evaluation of $\gamma$-enolase as a tumor marker for lung cancer. Cancer 60, 362-369.

17. Gerbitz, K.-D., Summer, J., Schumacher, I., Arnold, H., Kraft, A. \& Mross, K. (1986) Enolase isoenzymes as tumor markers. J. Clin. Chem. Clin. Biochem. 24, 1009-1016.

18. Jaques, G., Bepler, G., Holle, R., Wolf, M., Hannich, T., Gropp, C. \& Havemann, K. (1988) Prognostic value of pretreatment CEA, NSE and CK-BB levels in sera of patients with small cell lung cancer. Cancer 62, 125-134.

19. Johnson, D. H., Marangos, P. J., Forbes, J. T., Hainsworth, J. D., Van Welch, R., Hande, K. R. \& Greco, F. A. (1984) Potential utility of serum neuron specific enolase levels in small cell carcinoma of the lung. Cancer Research 44, $5409-5414$.

20. Kato, K., Ariyoshi, Y. \& Nakajima, T. (1985) Creatine kinase $\mathrm{B}$ subunit as a biomarker for small cell carcinoma of the lung; comparison with $\gamma$-enolase. Jpn. J. Cancer Res. (Gann) 76, 1162-1167.
21. Togawa, T., Higushi, Y. \& Kimura, K. (1987) TI/Ga uptake ratio in small cell carcinoma of the lung; with special reference to serum neuron-specific enolase and prognosis. Oncology 44, 228-231.

22. Tamura, S., Fujioka, H., Nakano, T., Hada, T. \& Higashino, K. (1987) Serum pseudouridine as a biochemical marker in small cell lung cancer. Cancer Res. 47, 61386141.

23. Ganz, P. A., Yeung Ma, P., Wang, H.-J. \& Elashoff, R. M. (1987) Evaluation of three biochemical markers for serially monitoring the therapy of small-cell lung cancer. J. Clin. Oncol. 5, 472-479.

24. Krauss, S., Macy, S. \& Ichiki, A. T. (1981) A study of immunoreactive calcitonin, adrenocorticotropic hormone and carcinoembryonic antigen in lung cancer and other malignancies. Cancer 47, 2485-2492.

25. Waalkes, T. P., Abeloff, M. D., Woo, K. B., Ettinger, D. S., Ruddon, R. W. \& Aldenderfer, P. (1980) Carcinoembryonic antigen for monitoring patients with small cell carcinoma of the lung during treatment. Cancer Res. 40, $4420-4427$.

26. Paus, E. (1988) Neuron specific enolase. Scand. J. Clin. Lab. Inv. 48, suppl. 190, 49.

Dr. M. P. van Dieijen-Visser

Department of Clinical Chemistry

De Wever Hospital

P. O. Box 4446

NL-6401 CX Heerlen 
, 